JPPUMA: Jurnal Ilmu Pemerintahan dan Sosial Politik UMA Uournal of Governance and Political Social UMA), 8 (2) (2020): 154-161, DOI: https://doi.org/10.31289/ippuma.v8i2.36198

JPPUMA: Jurnal Ilmu Pemerintahan dan Sosial Politik UMA

(Journal of Governance and Political Social UMA)

Available online http://ojs.uma.ac.id/index.php/ippuma

\title{
An Analysis of Actors in the Implementation of Public Policy on Accessibility of Persons with Disabilities for Work in Indonesia's Special Region Yogyakarta
}

\author{
Muhammad Akbar Maulana*, Dian Eka Rahmawati \& Achmad Nurmandi \\ Government Science Study Program, Faculty of Social and Political Sciences \\ Universitas Muhammadiyah Yogyakarta, Indonesia
}

Received: April 22, 2020; Reviewed: May 31, 2020; Accepted: June 16, 2020

\begin{abstract}
This study aims to analyze the implementation of public policy on the accessibility of persons with disabilities to get a job in Yogyakarta. It focuses on the actors implementing the policy in the Indonesian region, namely the provincial government of Yogyakarta as the implementer and policymaker, private companies, and Non-Government Organization (NGOs), which should be the stakeholders of the policy, program, and activities in distributing labors with disabilities. To approach this problem, the researchers use the theory of Van Meter and Horn as a reference. Data have been collected through interviews and documentation that later on analyzed qualitatively with the software of NVivo 12 plus. This study concludes that providing employment opportunities for persons with disabilities has not been implemented optimally. First, it is due to the absence of aftercare services, namely follow-up assistance for persons with disabilities after participating in training and rehabilitation programs held by the Regional Government. Secondly, law enforcement in the policy implementation that is pro disabilities (inclusion) to private companies is not optimal. Third, the lack of coordination among the actors in the efforts of empowering persons with disabilities.
\end{abstract}

Keywords: Policy; Implementation; Disability

How to Cite: Maulana, M.A., Rahmawati, D.E., \& Nurmandi, A., (2020). An Analysis of Actors in the Implementation of Public Policy on Accessibility of Persons with Disabilities for Work in Indonesia's Special Region Yogyakarta. JPPUMA: Journal of Governance and Social Politics UMA Journal of Social and Political Governance UMA), 8 ( 2 ): 154-161

*Corresponding author:

E-mail: Akbarmaulana.am344@gmail.com
ISSN 2549-1660 (Print)

ISSN 2550-1305 (Online) 


\section{INTRODUCTION}

Human rights are the rights of all people, which are inherent in humans who are also endowed with a mind and conscience. Human rights are universal in nature, meaning that they transcend national boundaries, and are addressed to everyone, whether poor or rich, male or female, persons with disabilities or nondisabled. Human rights are universal because they are stated as part of the life of every human being, regardless of skin color, gender, age, cultural and religious background, or spiritual beliefs (Hamidi, 2016).

Given the international law relating to the rights of persons with disabilities, there are at least two instruments that regulate the rights of persons with disabilities, in particular on employment rights. First, the United Nations Convention on the Rights of Persons with Disabilities in 2006 along with optional protocols, which are the most achievements for international legal instruments, especially concerning disable persons. Indonesia ratified the convention in November 2011 by Law No. 19 of 2011 concerning the Ratification of the Convention on the Rights of Persons with Disabilities) (Zulkarnain, 2008) .

The 1945 Constitution as a structural foundation in the life of the nation-state of Indonesia states in Article 27 paragraph (2) that every citizen has the right to work and a decent job for a living as a human being. Until recently, the laws and regulations governing work issues, especially regarding job opportunities for people with disabilities, are based on Law No. 13 of 2003 concerning Manpower, hereinafter referred to as the Manpower Act. Article 67 paragraph (1) of Law No. 13 of 2003 states that employers who employ workers with disabilities are obliged to protect according to the type and degree of their disability. Meanwhile in Article 53 paragraphs 1 and 2 of Law no. 8 of 2016 concerning Persons with Disabilities explains that; (Jakarta International Labor
Organization, 2013) a) The Central Government, Local Government, StateOwned Enterprises and Region-Owned Enterprises are required to employ at least two percent of Persons with Disabilities of the number of employees; b) Private companies are required to employ at least one percent of Persons with Disabilities of the total number of employees.

In line with Law No. 13 of 2003 concerning Manpower which stipulates that persons with disabilities are also eligible for employment following the field and expertise (Siti, 2017). The Government of the Special Region of Yogyakarta refers to the law to regulate this issue in the Regional Regulation (Peraturan Daerah/Perda) of the Special Region of Yogyakarta Number 4 of 2012 concerning the Protection and Fulfillment of the Rights of Persons with Disabilities. Article 16 of the regulation states that "Every Person with Disabilities has equal rights and opportunities for getting a job and/or doing a decent job ".

The Special Regional Government of Yogyakarta reiterates in Article 17 of the regulation that "Every worker with disabilities has the right and opportunity to get job training to equip and improve their competence according to individual conditions and needs" (The Government of the special region of Yogyakarta, 2012).

The Yogyakarta Special Region Department for Manpower and Transmigration (Disnakertrans) declared that there are still many companies that have not been able to accommodate workers from people with disabilities because they have not been able to provide adequate facilities and infrastructure to accommodate workers with disabilities (Utami, 2015).

The opportunity should certainly be concerned with and adapted to the type and level of disability, education, and skills possessed by persons with disabilities. Meanwhile, the quota for persons with disabilities must be adjusted 
to the number of employees and the qualifications of the company (Colbran, 2010).

The number of companies in Yogyakarta that accept workers with disabilities is still minimal (Mashur, 2017). Ideally, private companies must accept at least one worker with a disability who meets the requirements of the position and job qualifications as workers in their company for every hundred workers (Tosirin, 2017)

The Manpower and Transmigration Department (Disnakertrans) of Yogyakarta announces that twenty-three companies employ people with disabilities. The data is based on annual monitoring by the Manpower and Transmigration Department of Yogyakarta on the number of people with disabilities who are already working in the formal sector (Hammaa, 2017)

The issue of providing employment opportunities for persons with disabilities is a complex problem that requires comprehensive attention and participation, especially for the government, both the central government and local governments (Padmi, 2016)

The Head of the Division of Institutional Development for Job Placement and Marketing of the Manpower and Transmigration Department (Disnakertrans) of the Special Region of Yogyakarta explains that the Regional Government has socialized regulations regarding the implementation of job opportunities for persons with disabilities by encouraging companies in the region to provide the widest possible opportunity for persons with disabilities to access the labor market (Shalehah, 2014).

The reality above shows that there are legal issues that are interesting to be studied critically, which are related to the government's inconsistency. It is related to the position of the government as the actor of policy implementation that should provide opportunities for employment for persons with disabilities and protect human rights in the principle of the rule of law, which is not running optimally.

Without effective implementation, public policy cannot be successfully executed. Policy implementation is an activity that manifests after a valid direction of the policy has been issued which includes efforts to manage input to become an output or outcome for society (Edward III, 1984).

Policy implementation connects policy objectives and their realization with the results of government activities. This is following the views of Van Meter and Horn (Grindle, 1980) that state that policy implementation is responsible for building networks that enable public policy objectives to be realized through the activities of government agencies involving various interested stakeholders.

This research also applies the theory Public Policy Implementation by Van Meter and Horn associated with six variables in the implementation, namely; policy quality, adequacy of policy inputs, appropriateness of instruments, the capacity of implementers, characteristics of group support, and environmental coordination.

\section{RESEARCH METHODS}

This study employs qualitative methods. It compares trustworthy information that can be obtained, namely by explicating to explain and accurately describe the characteristics of an individual, condition, phenomena, or a certain group or to determine whether there is a relationship between a tendency and other phenomena in society (Moleong, 2002).

This study was conducted to investigate how the actors implement the public policy with some components of regulations that have been made to accommodate the people's needs, especially persons with disabilities in finding employment. The data used in this research are sourced from observation in 
the Department of Manpower and Transmigration, and Department of Social Service of Yogyakarta, namely by conducting interviews with officers in the field who have sufficient information and routine activities with persons with disabilities, 11 reputable national online news portals, Law, and Local Regulations regarding the protection and fulfillment of the rights of persons with disabilities.

The data analysis technique that is appropriate for this research is by using software to analyze computer-based qualitative data, namely using the latest updated application of Nvivo version 12 plus. NVivo is a tool used for coding the data obtained from interviews, journal articles, web pages, social media, and video to be converted into percentage form of tables and graphs so the readers can understand it. The data coding using indicators has been chosen following the objectives of this study, namely the data from interviews and web pages (Zamawe, 2015).

\section{RESULTS AND DISCUSSION}

Equalization for the disabled is an important goal of the policy implemented by the government of Yogyakarta to treat people equally based on human rights and without discrimination, especially concerning the issue of getting a job. Given that the number of people with disabilities has increased every year until 2019, which reach 29,025 people in Yogyakarta (Bappeda DIY, 2017). The lack of distribution and acceptance of employment with disabilities worsens the implementation of the government's policy which should be able to accommodate the disabled through local regulations that have been enacted.

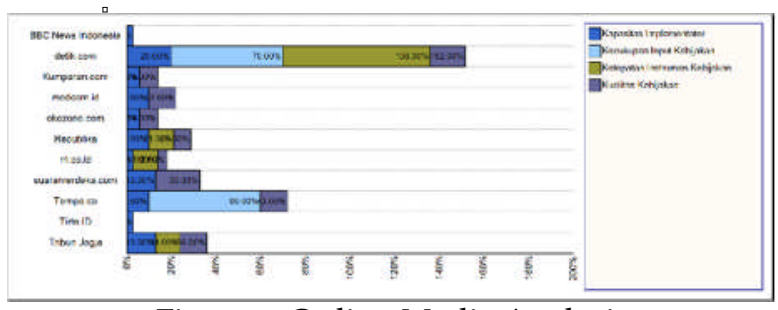

Figure 1. Online Media Analysis

Source: Processed by the authors using Nvivo 12, 2019

According to figure 1, the main point highlighted is the capacity of the implementor, who should be in the front line of all activities, and the implementation of training for persons with disabilities to prepare them for a more competitive job market.

From the release of 11 national media, it is stated that the involvement of the implementer (i.e. government) in policy implementation does not run with the maximum as it should. It is supposedly due to the executing tasks in the field do not have the capacity that is qualified to manage a program that aims to provide a positive impact on persons with disabilities.

The local government as the implementer and in charge of the policy must be able to accommodate the persons with disabilities following the mandate that has been regulated in the Regional Regulation No. 4 of 2012 on the Protection and Fulfilling the Rights of Persons with Disabilities.

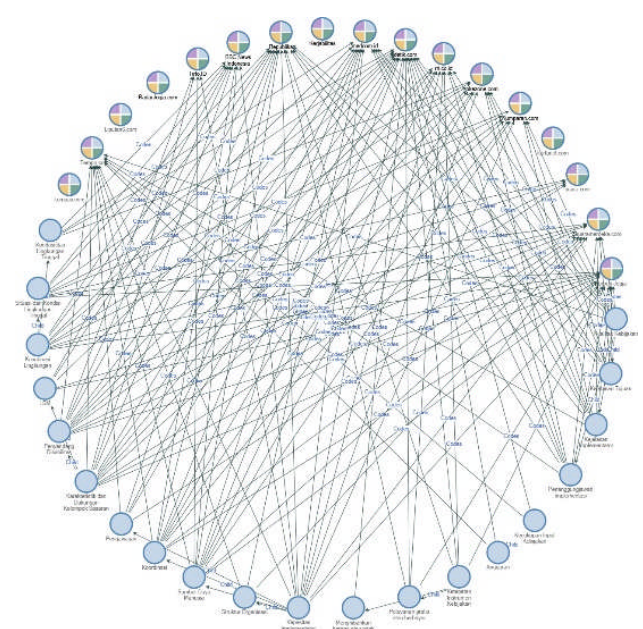

Figure 2. Relationship between indicators and Web News

Source: Processed by the author using Nvivo 12, 2019 
Figure 2 shows that the national news portal has much to do with the problems that occur concerning the protection and fulfillment of the rights of persons with disabilities in the Special Region of Yogyakarta, particularly related to the accessibility of getting jobs. The media that filtered the most informants related to these problems were Detik.com, Republika, Tempo, and Tribun Jogja, which state that concern for people with disabilities today is only limited to the concepts and regulations, but in the concrete manifestation of how to accommodate and provide proper facilities for people with disabilities are still very minimum.

As reported in the news pages Tempo.com, the article suggests that persons with disabilities have been made as to the object of the regulations that are made to increase the state expenditure spent in the region, but the important part where the disabled should be the subject that is encouraged to become prosperous under regulatory mandates was not carried out properly.

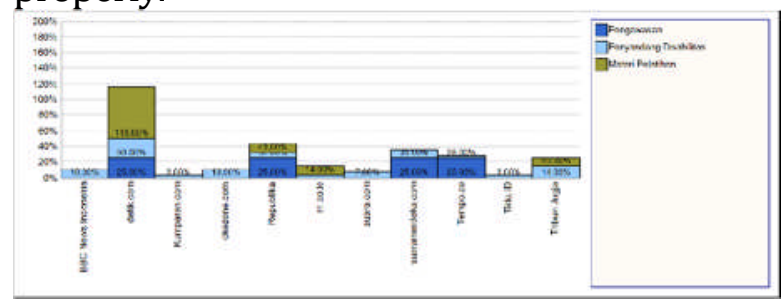

Figure 3. The Analysis of Obstacle

Source: Processed by the author using Nvivo 12, 2019

Figure 3, illustrates that many problems occurred regarding the implementation of the Regional Regulation (Peraturan Daerah/Perda) No. 4 of 2012 on the Protection and Fulfilling the Rights of Persons with Disabilities.

First, the government's role is not dominant, which on average only reaches 25 percent, in terms of monitoring companies in enforcing quotas related to regulations for persons with disabilities to find work. This shows that supervision has not been running optimally. The quota policy seems to come to a stop at regulation without any follow-up in the form of 'reward and punishment'. This has resulted in the disobedience of many public agencies and private companies to implement this quota policy. Most companies that employ people with disabilities are middle to lowerscale companies whose company leaders are coincidentally the persons with disabilities.

Second, the portion of 14 percent illustrates that the training materials provided for persons with disabilities are not updated so that there are very few skills available. While the job market requires high productivity.

The Department of Social Service and the Department of Manpower and Transmigration of the Special Region of Yogyakarta as executors are less interactive so that they are monotonous and seem less adapted to the needs of the job market. Several courses are given but still adopt the old methods, such as sewing, embroidery, carpentry, and screen printing. Ideally, training materials and activity programs must be adjusted to the demands of the current job market, for example, training on computers and other information technology.

Third, the conditions of persons with disabilities themselves. The portion of 3 percent indicates that there is a root problem that is not resolved yet. The conduciveness of the environment in which the disabled lives is significant in influencing their daily activities. This becomes very important because if the environmental conditions alone do not support disabled people in their activities, then, it must be hampering their productivity. Many cases show that the unconducive environmental conditions do not support the development of creativity, in which people with disabilities prefer the streets to earn a living or income to fulfill their daily life. In this case, the methods that they use for a living are certainly improper such as begging and busking.

The process of implementing a policy certainly requires an executor who is qualified in his or her field of expertise, so that he or she can manage every activity well following the regulations set by the regional government. If the executors of the activity are unable to accommodate all forms of activities and programs, they will not be able to carry out the program and activities stipulated in the regional regulations. 
A local policy must be based on considerations of the benefit for the communities, which certainly can not be ignored. The large demands of the community that are widely expressed in regional regulations can certainly have a positive impact on each activity.

○'

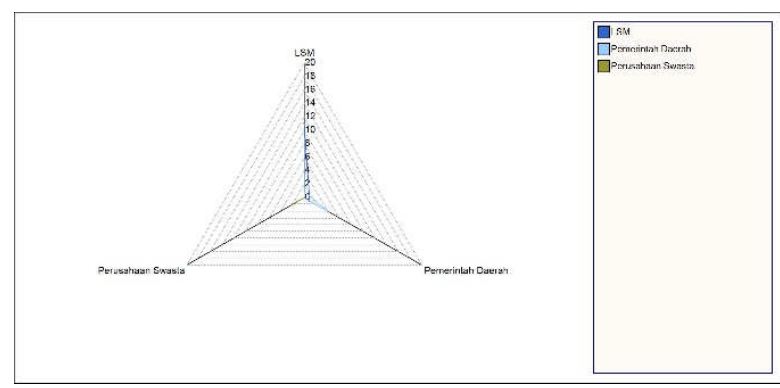

Figure 4. Analysis of Policy Actors

Source: Processed by the author using Nvivo 12, 2019

In Figure 4, there are 3 implementing actors executing the policy for the accessibility of job opportunities for persons with disabilities in the Special Region of Yogyakarta. The dominant role of NonGovernment Organization/NGOs (Lembaga Swadaya Masyarakat/ LSM) to accommodate every activity for persons with disabilities is very noticeable that surpass 10 grade. Many interesting innovations conducted by NGOs to accommodate persons with disabilities to get a decent job, either in terms of education or job training. One of them is creating a tool of application for jobs through websites and smartphone applications to make it easier for people with disabilities to access jobs.

The role of the government, which is highly expected but not dominant, is at grade 3 . The government is still using outdated training methods and materials, which result in the low quality and low skilled people with disabilities who are not ready to compete in the modern and digital work field. The demands of companies are no longer only productivity but also an innovation make persons with disabilities unable to participate in the productive competition.

These high demandsmake private companies reluctant to employ people with disabilities. The above picture shows that only 1 point refers to private companies, which indicates that the focus of attention of private companies is on their productivity. Their mindset is that people with disabilities cannot work quickly according to the demands of the company. Even though this is not always the case if the education and training provided by the government running optimally following developments in the modern industry. Besides, there is no exact consequences or firm sanction from the government for private companies that do not accommodate work quota for persons with disabilities. This certainly makes private companies feel safe if they do not employ people with disabilities.

The Provincial Government of Yogyakarta through the Social Service Department and cooperation with private companies have made several efforts in the form of education, training, and job distribution. However, this requires the assistance of non-governmental organizations (NGOs) that pay more attention to the disabled, such as through the Loka Bina Karya activities.

The benefits and objectives of the Loka Bina Karya are to provide social services and rehabilitation for persons with disabilities. It also facilitates social welfare efforts, organize social services and rehabilitation including counseling, guidance, job skills training, distribution, as well as conducting productive business activities, which are cooperative.

Besides Loka Bina Karya, the provincial government of Yogyakarta also provides a series of training for persons with disabilities to improve the ability and skills to conduct job training; independent workforce training, and technical training. Some examples are training for skills in embroidery and sewing.

The types of training given to the disabled and the programs offered to them so far have no longer been able to answer the needs of disabilities in practical, which are skills that are ready for work. Besides the minimum number of training, the types of training are also no longer suitable for the needs of the current job market. 
The current need in the job market has demanded the multi-media and computer generation. Meanwhile, the training for the disabled still concentrates on sewing, carpentry, and screen printing. As the result, the trainees simply return to become workers who are no longer updated with the skills demanded by the job market. This is not to mention the testimony of several persons with disabilities who feel and know exactly how such pieces of training are held merely as a government project. This illustrates that the disabled so far are still positioned as objects and not subjects who know their problems and needs.

\section{CONCLUSION}

Policies that have been created specifically for persons with disabilities to get a job in government and private agencies not performing optimally in the Special Region of Yogyakarta. Efforts that the actors implemented to execute the policies to maximize the potential of the disabled and distribute them in the available job market have not been effective. There are several obstacles for persons with disabilities to be able to compete in the job market, including the lack of updated training materials for persons with disabilities so that the absorption of workers with disabilities is still very minimum. Also, the enforcement of regulations regarding the 2 percent and 1 percent quota for persons with disabilities to get a job has not been going optimally. There is low awareness of the implementing actors of the policy. In this case, the local governments and private companies employ people with disabilities very minimally due to productivity reasons and low willingness of persons with disabilities to try to find work in the available job opportunities.

\section{REFERENCES}

Bappeda DIY. (2017). Kebijakan pemda diy, Pemenuhan Hak Penyandang Difabel. (September).
Colbran, N. (2010). Akses Terhadap Keadilan Penyandang Disabilitas Di Indonesia.

Edward III, G. C. (1984). Public Policy Implementing. London-England: Jai Press Inc.

Grindle, M. (Ed. . (1980). Politics and Policy Implementation in the Third World. Retrieved from www.jstor.org/stable/j.ctt1m323qj\%0A

Hamidi, J. (2016). Perlindungan Hukum terhadap Disabilitas dalam Memenuhi Hak Mendapatkan Pendidikan dan Pekerjaan. Jurnal Hukum Ius Quia Iustum Facult of Law, 23(4), 652-671.

Hammaa, L. (2017). Kebijakan Pemerintah DIY Dalam Upaya Peningkatan Hak Ketenagakerjaan Bagi Penyandang Disabilitas. Journal of Personality and Social Psychology, 1(1), 1188-1197. https://doi.org/10.1111/j.14697610.2010.02280.x

Mashur, D. (2017). Implementasi Perda Nomor 18 Tahun 2013 tentang Perlindungan dan Pemberdayaan Penyandang Disabilitas di Pekanbaru (Studi kasus Penyediaan Aksesibilitas Bidang Sarana dan Prasarana Transportasi). Ilmu Administrasi Negara, 4(1), 1-14.

Moleong, L. J. (2002). Metodologi penelitian kualitatif (Edisi Revi). Bandung: PT Remaja Rosdakarya.

Organisasi perburuhan Internasional Jakarta. (2013). Pedoman ILO tentang Pengelolaan Penyandang Disabilitas di Tempat Kerja.

Padmi, T. (2016). Implementasi Aksesibilitas Pelayanan Informasi dan Pelayanan Khusus Bagi Penyandang Cacat di Kota Semarang. Sosio Konsepsia, 11(2), 66-71.

Pemerintah Provinsi Derah Istimewa Yogyakarta. Peraturan Daerah nomor 4 tahun 2012 tentang Perlindungan dan Pemenuhan HakHak Penyandang Disabilitas. , (2012).

Shalehah, I. (2014). Kesempatan Kerja Bagi Tunanetra (Studi Kasus Terhadap Anggota Ikatan Tunanetra Muslim Indonesia Kota Yogyakarta). 8(33), 44.

Siti, A. (2017). Implementasi Kebijakan Aksesibilitas Pelayanan Bagi DIfabel di Yogyakarta Tahun 2015. Kebijakan Dan Manajemen Publik, 3(4), 1-24. https://doi.org/10.1016/j.cell.2009.01.043

Tosirin, A. (2017). Pelaksanaan Pemberian Kesempatan Kerja Bagi Penyandang Disabilitas Netra Di Daerah Istimewa Yogyakarta. Journal of Personality and Social Psychology, 1(1), 1188-1197. https://doi.org/10.1111/j.14697610.2010.02280.x

Utami, D. (2015). Implementasi Kebijakan Kuota Bagi Penyandang Disabilitas Untuk 
JPPUMA: Jurnal Ilmu Pemerintahan dan Sosial Politik UMA (Journal of Governance and Political Social UMA), 8 (2) (2020): 154-161

Mendapatkan Pekerjaan Di Kota Yogyakarta. Zulkarnain, R. (2008). Perlindungan Hak-Hak 3, 67-83.

Konstitusional Penyandang Disabilitas

Zamawe, F. C. (2015). The implication of using NVivo software in qualitative data analysis: Evidence-based reflections. Malawi Medical Journal, 27(1), 13-15. https://doi.org/10.4314/mmj.v27i1.4 (Rights Of Persons With Disabilities). The Visual Computer, 24(3), 155-172. 